\title{
Workplace Abuse and Harassment: The Vulnerability of Informal and Migrant Domestic Workers in Portugal
}

\author{
Maria da Conceição Figueiredo*, Fátima Suleman** \\ and Maria do Carmo Botelho*** \\ *Instituto Universitário de Lisboa (ISCTE-IUL), BRU-IUL, Lisboa, Portugal \\ E-mail: Conceicao.Figueiredo@iscte.pt \\ **Instituto Universitário de Lisboa (ISCTE-IUL), DINÂMIA'CET-IUL, Lisboa, Portugal \\ E-mail: Fatima.Suleman@iscte.pt \\ ***Instituto Universitário de Lisboa (ISCTE-IUL), CIES-IUL, Lisboa, Portugal \\ E-mail: Maria.Botelho@iscte.pt
}

Policy makers and researchers are alarmed by the pervasive substandard working conditions and mistreatment in domestic work worldwide. Using an original dataset from a sample of domestic workers in Portugal $(n=684)$, our study explores types of abuse and harassment and tries to unveil the potential factors affecting the likelihood of having been a victim. Empirical evidence pointed to three segments of domestic workers: victims of labour abuses related to contract and wages, victims of multiple abuses including mistreatment and also psychological and sexual harassment, and a segment with no occurrence of abuse. Informal workers are more often victims of labour abuses, while migrants, especially Brazilian women, are more likely to report all types of abuse and harassment. On the other hand, carers of the elderly often suffered multiple abuses. The results suggest that despite the prevalence of labour abuses in Portugal, the most severe abuses are uncommon.

Keywords: domestic workers, abuse and harassment, working conditions, informality, migration.

\section{Introduction}

Certain occupations, circumstances in which people work and gender can significantly increase the risk of violence in the workplace (Chappell and Di Martino, 2006; Mayhew, $2012^{1}$ ). In domestic work, all these elements combine to increase the likelihood of abuse; workers, often female migrants, work for households to care for the home, for the elderly or children. This is the case of caregivers and immigrants, who are employed in particularly vulnerable conditions. This is the case of caregivers and immigrants, who are employed in particularly vulnerable conditions.

The literature provides clear evidence of the lack of social recognition and undervaluing of domestic work, including care work (Kontos, 2014), and that most domestic workers worldwide are employed in substandard conditions and are vulnerable to multiple abuses and harassment in their workplace (ILO, 2010, 2013; Caracciolo et al., 2011). These abuses and harassments are frequently invisible to researchers 
and policy makers, in part because domestic workers work in a private house, but also because many of them, especially migrants, often have an undeclared working relationship. While available research highlights the greater vulnerability of migrants (e.g. Cruz and Klinger, 2011; Huling, 2011), it has not adequately explored other factors that affect the probability of abuses in the workplace or that reduce this risk.

This study uses dedicated data from a survey of domestic workers in Portugal $(n=684)$ with two interrelated objectives. First, it analyses the different kinds of mistreatment suffered by domestic workers. Following the available literature that differentiates several types of abuse (e.g. Bakan and Stasiulis, 1997; Pereira and Vasconcelos, 2008; Mayhew, 2012), we use multiple correspondence and cluster analysis to classify the abuses and harassments reported by the sampled domestic workers. The second stage of the study tries to unveil the predictors of each type of abuse. We apply a multinomial regression model to examine how the current characteristics of domestic workers, their knowledge of legal rights, their employment relationship and jobs characteristics are associated with the probability of having been a victim of a particular type of abuse.

The Portuguese labour market is attractive to migrants, especially from Portuguese speaking ex-colonies and Eastern European countries (Wall and Nunes, 2010; Abrantes, 2012); like native women, they see domestic work as a job opportunity because there is a strong demand for these services due to the poor provision of state care (Leitner, 2003). Families in Mediterranean countries rely on women and foreign domestic workers to assist in the provision of care because there is weak state support (León, 2010; Wall and Nunes, 2010; Jokela, 2015). Despite demand for such services, research shows that domestic workers in Portugal are also vulnerable to various types of abuse (Pereira and Vasconcelos, 2008).

These workers are hired under a variety of contractual arrangements that are quite often informal and flexible. Our study employs a unique dataset to answer the following questions: Which types of abuse prevail in the labour market? Are migrants more exposed to abuse than Portuguese workers? If so, are all migrants equally mistreated or is there a racial hierarchy? What is the relationship between the type of employment relationship employers are willing to offer and the type of abuse reported by domestic workers? Are informal workers more likely to report abuse? Are there any characteristics of the worker or the work that lessen the likelihood of abuse?

Ultimately, our aim is to explore the extent to which the violence at work is rooted in characteristics that foster or prevent the abuse in domestic work. While some predictors have already been tested in the literature, others deserve further scrutiny. We discuss the factors that may reduce employers' discretion on the working conditions given to domestic workers. Our study therefore addresses an important issue of domestic work and makes a valuable contribution to the literature which has examined this topic mainly from the perspective of factors that increase vulnerability.

The remainder of the paper is structured as follows. The next section discusses the relevant literature on abuse and on predictors of this abuse worldwide and in Portugal. The third section details the dataset and the methodological methods used to deal with the data, and the forth section gives the empirical results. The final section presents the discussion and some concluding remarks. 


\section{Violence in private households}

Abuse and harassment in domestic work

Violence in the workplace includes a variety of hostile behaviours that affect workers, irrespective of gender or occupation. The victims of mistreatment often lack power in their employment relationship, have limited protection or job alternatives (Chappell and Martino, 2006). This is certainly the case of domestic work in which non-family members, usually women and migrants, perform household tasks such as housekeeping and caring (Moya, 2007).

Literature shows that mistreatment is common in domestic work. It is quite impossible to examine the activity without addressing or detailing the disadvantages of domestic work and noting the different kinds of abuse and mistreatment suffered by domestic workers (e.g. Arat-Koc, 1989; Glenn, 1992; Bakan and Stasiulis, 1997; Parreñas, 2000; Anderson, 2004; Burnham and Theodore, 2012). Abuses in domestic work can be categorised as type $\mathrm{II}^{2}$ (Merchant and Lundell, 2001), where the perpetrator is usually the care receiver and the violence occurs during the work-related interaction. Domestic workers belong to a high-risk group for gender-based violence (Cruz and Klinger, 2011).

Scholarly research as well as the press and reports from international institutions document the various types of abuse suffered by domestic workers worldwide (e.g. Bakan and Stasiulis, 1997; Burnham and Theodore, 2012; ILO, 2013). Bakan and Stasiulis (1997) use the label of 'labour abuses' to describe the mistreatment associated with wages and contracts. They report the non-payment of wages, wages arrears, underpayment of wages, excessive working hours, non-payment of overtime and breach of contractual agreements. However, other less explicit abuses also occur in domestic work. Employers often define spatial arrangements, such as separate entrances, separate stairwells, outdoor toilets (Lan, 2003) to underline the inferiority of domestic workers.

Domestic workers are sometimes also victims of more severe abuse and harassment. Reports of mistreatment make references to verbal, psychological, physical and sexual abuse and harassment, including rape (Bakan and Stasiulis, 1997; Burnham and Theodore, 2012); forced labour (Huling, 2011); the obligation to live in the employer's house (Lin, 1999); imprisonment in the employer's house (Jureidini and Moukarbel, 2004); the control of food consumed (Lan, 2003), that is, employers define the quantity and quality of food available for domestic workers; substandard accommodation in the case of live-in workers (Arat-Koc, 1989; Bakan and Stasiulis, 1997); and even death (Rodriguez, 2008).

Pereira and Vasconcelos (2008) describe the prevalence of 'labour abuses' in Portugal, notably non-payment or non-compliance with the requirement to declare the employment relationship to social security authorities; and hiring without a written or legally valid contract. Employers foster the informal employment relationship that pervades domestic work and Abrantes (2012) draws attention to their unwillingness to declare this relationship to social security and to pay the respective contributions.

Other common 'labour abuses' in Portugal are the non-payment of overtime for livein workers; and working hours for live-out workers vary such that the contracted working hours, and consequently wages, are reduced at the employer's discretion, depriving these workers of income security. Abrantes (2012) notes the violation of labour rights, namely non-payment of Christmas and holiday bonuses, non-provision of maternity leave and non-payment of health care in cases of work accidents. 
Studies on the Portuguese labour market also suggest some occasional or rare situations of severe abuse such as psychological coercion, extortion and retention of documents (Pereira and Vasconcelos, 2008). However, migrants are particularly vulnerable to certain types of abuse, which we detail in the next section.

\section{Predictors of abuse and harassment in domestic work}

The literature on abuse and harassment in domestic work suggests that certain categories of workers and employment relationships make domestic workers especially vulnerable to mistreatment. The research on abuse thus strives to examine the factors that increase the likelihood of becoming a victim.

Migration and racial hierarchy. The literature provides clear evidence that migrants are the most vulnerable category in the labour market of domestic workers. Empirical data suggest that migrant domestic workers are severely mistreated and exploited worldwide, ${ }^{3}$ though especially in some countries, and are often more discriminated than their native-born counterparts. Below, we present an overview of this literature.

Bakan and Stasiulis (1997) argue that domestic workers all over the world face abuse and that the mistreatment differs in degree rather in kind. Huling (2011) focuses on the forced labour of Indonesian migrants in Malaysia and states that unregulated employment relationships make these workers vulnerable to human trafficking. Lin (1999) reports unequal treatment of migrant and native domestic workers in Taiwan. Whereas the former are obliged to live in their employer's home in Taiwan, native workers tend to be part-time cleaners, earn higher wages and benefit from greater flexibility and autonomy. Lan (2003) also draws attention to the marginalisation of migrant workers in Taiwan, reflecting class and ethnic stratification, and to spatial segregation. Chappell and Martino (2006) describe the fear of deportation among African workers in Egypt that heightens the risk of their becoming victims of violence; they also note the lack of labour laws covering domestic workers in Saudi Arabia. Singapore imposes restrictions on marriage and cohabitation with Singaporeans or permanent residents, and becoming pregnant (Bakan and Stasiulis, 1997). Jureidini and Moukarbel (2004) use the label 'contract slavery' to report abuses against temporary Sri Lankan migrant workers in the Lebanon.

However, even countries with more liberal regimes and favourable conditions for migration such as Canada are not without various types of abuse (Bakan and Stasiulis, 1997). Anderson (2004) reports physical, psychological and sexual violence suffered by migrant domestic workers in the UK, while Burnham and Theodore (2012) note similar mistreatment in the US. The authors stress that employers in the US also fail to provide benefits, pay social security contributions, overtime or to allow time for rest and sufficient sleep. Pereira (2013) and Pereira and Vasconcelos (2008) underline the greater vulnerability of migrants in Portugal, notably discrimination in access to work. ${ }^{4}$ However, it is 'labour abuses' that are most frequently reported by migrants in Portugal.

Further insights are drawn from reports in newspapers and online blogs of mistreatment and violations of legal rights in Portugal. They also reveal discrimination on the grounds of ethnic origin. Gomes (2012) refers to the employers' perceptions of different ethnic origins when hiring a worker in Portugal: Africans are considered more docile, Brazilians more sensual and Eastern European more educated. Pereira (2013) and Pereira and Vasconcelos (2008) identified a preference for the latter not only because they have better qualifications, but also for their learning ability and work discipline. 
Language and cultural proximity explain a preference for Brazilians, especially in livein arrangements for care work (Wall and Nunes, 2010). Finally, Africans are thought to accept lower wages and long working hours.

Migrant domestic workers express concern about having to perform whatever task they are asked to do, including taking care of animals, and about the employer being able to terminate the employment relationship without any legal repercussions (Gomes, 2012). Migrants from ex-colonies interpret mistreatment as a legacy of the colonial mentality in that employers are unwilling to treat them with dignity and respect.

Sexual and psychological harassment has also been the subject of insufficient attention in the literature. Once again, the press and migrant aid agencies in Portugal are an important source of this data. 'Comunidária' ${ }^{5}$ - a migrant aid agency - receives around two hundred complaints of harassment a year. Most of these refer to psychological harassment (90 per cent), as victims are probably ashamed or afraid to report cases of sexual harassment. The few statements on the latter come from Brazilian workers and indicate that live-in workers are more vulnerable and that employers make sexual favours a condition for a formal contract. The data not only suggest that there are preconceptions about different ethnic origins but that these might be associated with particular kinds of abuse. $^{6}$

The evidence reported sheds light on the relevant predictors of abuse in Portugal and underlines the vulnerability of migrants. Reyneri (2003), Gomes (2012) and Pereira (2013) also note that informality, undeclared work and irregular migration help perpetuate unfavourable conditions. For Kontos (2013), there is a 'tacit acceptance of irregularity' that enables families, especially in Southern European countries, to meet their needs for domestic and care work.

Based on previous studies, we suggest migrant domestic workers are more vulnerable to abuse (Hypothesis 1).

Moreover, there is an intersection between gender, race, ethnicity and citizenship in paid domestic work (Glenn, 1992; Romero, 1992; Anderson, 2001; Raghuram, 2001; Moya, 2007), which mutually reinforces disadvantages and contributes to pervasive substandard conditions. Not surprisingly, the abuse and harassment in domestic work is part of the academic and political discussion about the global migration of female workers who migrate in the hope of finding better employment conditions in the host countries (Ehrenreich and Hochschild, 2002).

It should also be noted that there is a social hierarchy within the segment of migrant domestic workers in countries where migrants of different origins compete for jobs. Employers base their decision to offer a job on preconceived ideas about the characteristics of particular nationalities or ethnicities (Jureidini and Moukarbel, 2004; Anderson, 2007). This not only entails racial discrimination but also cumulative disadvantages. Drawing on Boyd and Pikkov (2008), we note stratification based on gender, nationality and ethnicity underlying the 'triple' prejudice that domestic workers face, namely as women, migrant women and migrant women of a specific origin.

We believe there is a racial hierarchy within the migrant status (Hypothesis 2).

Legal rights: initiatives and knowledge. International and national bodies have taken decisive steps to promote decent work for domestic workers (see Blackett, 2011, for details). Blackett stresses that transforming the status relationship, notably associated with domestic slavery and forced work, to a work relationship with labour rights and dignity is the essence of the law and the practice in initiatives promoted by the International 
Labour Organisation (ILO). Therefore, it is vital to adopt the ILO Convention 189, more specifically, to include domestic work in the scope of labour legislation; provide social protection and equitable pay, including minimum wage; and guarantee the right to create or join trade unions and to collective bargaining (Blackett, 2011; Caracciolo et al., 2011).

Domestic workers in Portugal enjoy the same access to legal and social protection as other employees. Social protection was extended to domestic workers in the late 1960s before the end of the fascist regime, and the relevant labour legislation dates back to the 1980s and 1990s. Decree-law 235/92 sets out the working conditions employers must provide and it covers the tasks to be performed, pay and pay components including paid holidays and Christmas bonus, among others. Furthermore, domestic workers are entitled to the national minimum wage and social security contributions are compulsory (for more details on legal rights see Suleman, 2015). Recently, the Portuguese Government ratified the ILO Convention 189 (Parliament Resolution 42/2015) and it is expected to implement these recommendations.

However, domestic workers (but also employers) often have little knowledge or awareness of their legal rights (Liu, 2014). Migrants may have language difficulties and know nothing about the law in the host country; Jureidini and Moukarbel (2004) stress that even when contracts are translated, it is often into English and details are frequently not understood. Thus, migrants are less likely to know their legal rights and to fight for them.

In fact, domestic workers, and especially migrants, are often categorised as modern slaves (Anderson, 2004) without rights as citizens or workers. The literature suggests that the lack of labour laws protecting domestic workers contributes decisively to the risk of abuse. Domestic workers' lack of knowledge of the law and their rights exposes them to the risk of exploitation and the violation of rights and freedom (ILO, 2013). Portuguese bodies have actively sought to prepare and disseminate appropriate material and information regarding domestic work due to the fact that a knowledge of legal rights helps protect domestic workers against the risk of abuse (Hypothesis 3), (e.g. GAMI, 2012).

The employment relationship and job characteristics. Domestic workers are usually engaged in unequal power relationships (Meagher, 1997; Chen, 2011). The job is based on a mistress-maid relationship in which the employer, usually a woman, exploits the employee, also usually a woman (Rollins, 1985; Arat-Koc, 1989); employers also underline their superiority by developing maternalist relationships with their domestic workers (Rollins, 1985).

Employers use the metaphor 'one of the family', assuming that the relationship with the domestic worker is familial more than contractual. (Anderson, 2000). Kontos (2014) defines it as 'fictive family', to express the contradiction between economic needs and family especially in care work. It is also suggested that 'one of the family' is used to undermine the legal status of domestic workers and facilitate the hiring of cheap and flexible labour (Um, 2015) and therefore masks exploitative situations affecting workers' wages and employment rights.

This is particularly the case of live-in domestic workers, who are often isolated from their own families and support systems (Kontos, 2014). They are paid low wages despite long working hours (Pereira and Vasconcelos, 2008; Cruz and Klinger, 2011), have no rest day (Pereira and Vasconcelos, 2008) and little access to a phone, mail or the 
internet (Burnham and Theodore, 2012) - ultimately, they are exploited. As reported, the employment relationship and social relations with their employers tend to overlap and they are expected to make sacrifices as if they were part of the family (Bakan and Stasiulis, 1997; Kontos, 2014). It is reasonable to expect that live-in workers are more vulnerable to abuse than other domestic workers (Hypothesis 4).

Employers sometimes try to make domestic workers feel like one of the family by giving advice assistance and gifts out of kindness, benevolence or to demonstrate care (Bakan and Stasiulis, 1997; Kontos, 2014; Tappert and Dobner, 2015). Gifts can range from old or second-hand clothes, to furniture and gadgets, and left-over food (Bakan and Stasiulis, 1997); but there are also examples of more expensive support like paying for children's education (Kontos, 2014). Employers also sometimes allow workers to bring their children to work (Tappert and Dobner, 2015).

However, it is argued that these 'gifts' reinforce the inequality and asymmetry of the employment relationship. They are substitutes for benefits or higher wages (Romero, 1992) and lead to demands for loyalty and reciprocity, notably expecting workers to be available at any time, or to do overtime without pay (Kontos, 2014; Tappert and Dobner, 2015).

We therefore suggest that employers use mechanisms to underline an asymmetric relationship with their domestic workers and probably to reduce labour costs (Hypothesis $5)$.

Other predictors of the employment relationship should not be overlooked. Informal workers are inevitably more vulnerable to abuse. Cox and Watt (2002) detail the benefits of informality for employers: there is no need to give sick or holiday pay, to provide health and safety insurance and the worker cannot accuse the employer of unfair dismissal. Undocumented workers in the US are more likely to have lower wages and poor working conditions (Burnham and Theodore, 2012).

While there is some consensus among scholars on substandard working conditions, another stream of literature addresses the particularities of domestic work and examines how employers can offer these conditions without endangering their home and family members.

For example, Anderson (2007) notes that while employers can dismiss workers at will, the workers are equally free to renounce the contract and leave/change employer and some domestic workers, especially caregivers, are difficult to replace. Caring is associated with a personal relationship (Himmelweit, 2007) and involves emotional labour, affective relations and intimacy between the domestic worker and care receiver (Anderson, 2001; Dyer et al., 2008). De Ruijter et al. (2003) state that trust issues linked to the workplace and the nature of domestic work are a core problem in domestic work. Employers are usually absent and entrust their home, and often the keys to the house, and family members to people they hardly know. Therefore, references and recommendations from the employer's network are vital when hiring from the informal labour market (Moras, 2008). Suleman (2015) adds that informal and flexible domestic work is less likely when caring tasks, trust-related issues and skills are involved.

An empirical analysis should be made of the factors that affect the type of employment relationship employers offer to domestic workers. In this regard, we suggest job characteristics, including the workplace, the characteristics of the contract, the skills required and tasks to be performed; and trust-related issues are associated with the probability of having been a victim of mistreatment (Hypothesis 6).

The paper focuses on both the risk and protection factors that predict types of abuse and harassment in domestic work. The available literature has placed particular emphasis 
on factors that heighten vulnerability to abuse. In light of the argument made by Du Toit (2013), we claim that domestic workers will only obtain social recognition and respect if employers recognise domestic work as true employment as opposed to a private family arrangement. This in turn entails raising employers' awareness of the particularities of domestic work and especially of care work.

\section{Data and methodology}

The dataset

The empirical analysis draws on an original cross-sectional dataset of domestic workers in Portugal collected in 2010 for an international project (see Guibentif, 2011, for details). Given the characteristics of domestic workers and their workplace, snowball sampling was used to gain access to participants. The contact details of domestic workers were obtained from domestic work unions, immigration-related institutions and personal acquaintances. The data were gathered in face-to-face interviews and include information on socio-demographics, job and workplace characteristics $(n=684)$. It should however be noted that the sample is not fully representative of the population of domestic workers, so the conclusions drawn for this sample cannot necessarily be extended to the entire population.

Workers' own statements were the source of data about the abuse experienced. It has to be noted at the outset that, in some cases at least, there is probably a temporal mismatch between the current job and the experience of abuse.

The sampled workers gave yes/no responses to whether they had experienced one or more of the following situations: wages arrears, unpaid allowances, unpaid overtime, unpaid social security contributions; obligation to perform tasks not in the initial agreement, deprivation of rest time, deprivation of food, deprivation of holidays, sexual harassment, physical violence, psychological harassment, discrimination, obligation to perform tasks against their will and spatial segregation. The respondents were also asked if they received gifts from employers and, if so, what kind of gift.

We are in addition examining the association between workers, job and workplace characteristics and the probability of having been victim of a particular type of abuse. The characteristics include:

- Nationality - African, Brazilian, Eastern European and Portuguese.

- Formality - whether the domestic worker is registered with the social security institution; this indicates a formalised employment relationship.

- Knowledge of legal rights - whether domestic worker is willing to go to court citing illegal procedures.

- Job characteristics - live-in, single or multiple employers; skills required: personal traits; specific skills; flexibility; and general skills (see Table 1A in Appendix); additional requirements: whether employer demanded any specific skills; tasks performed: cleaning, child care, elderly care.

- Trust issues - whether the employer is present to control the worker; whether the worker has the key to the house; whether the employer demanded references.

- Employer's characteristics - workplace: apartment or house; maternalist relationship: whether employer offers gifts. 
Table 1 Frequency distributions of characteristics of domestic workers*

\begin{tabular}{|c|c|c|}
\hline Characteristics & $\mathrm{n}$ & $\%$ \\
\hline Gender: (Female $=1)$ & 681 & 99.7 \\
\hline \multicolumn{3}{|l|}{ Nationality: } \\
\hline African & 85 & 12.5 \\
\hline Brazilian & 84 & 12.3 \\
\hline Eastern European & 57 & 8.4 \\
\hline Native & 456 & 66.9 \\
\hline Formality: Social security $(Y e s=1)$ & 473 & 69.8 \\
\hline Knowledge of legal rights (Yes $=1$ ) & 440 & 66.1 \\
\hline \multicolumn{3}{|l|}{ Job characteristics: } \\
\hline Live-in status & 85 & 12.5 \\
\hline Multiple employers & 384 & 55.7 \\
\hline Single employer & 215 & 31.8 \\
\hline Additional skill requirement (Yes $=1$ ) & 186 & 27.4 \\
\hline \multicolumn{3}{|l|}{ Tasks performed: } \\
\hline Child care tasks & 212 & 36.1 \\
\hline Cleaning tasks & 287 & 32.4 \\
\hline Elderly care tasks & 185 & 31.5 \\
\hline \multicolumn{3}{|l|}{ Trust issues: } \\
\hline Employer present $($ Yes = 1) & 274 & 40.4 \\
\hline Key to the house $($ Yes $=1)$ & 511 & 75.3 \\
\hline Demand for references $($ Yes $=1)$ & 125 & 21.6 \\
\hline \multicolumn{3}{|l|}{ Employer characteristics: } \\
\hline Household (Yes = 1) & 248 & 36.7 \\
\hline Maternalist relationship: Gifts (Yes $=1$ ) & 401 & 58.7 \\
\hline Observations & 684 & 100.0 \\
\hline
\end{tabular}

Note: *Frequencies for personal traits, specific skills and general skills were not presented as they are standardised quantitative variables, resulting from the PCA analysis.

Note that the skills required in domestic work were assessed through the selfperception of relevant skills. The questionnaire included the following question: 'If you were an employer, which skills would you look for in a domestic worker?' It was assumed that the workers would mention the skills they considered appropriate to perform household tasks. This might proxy the skills required in the domestic work. The survey included further questions about the skills and abilities of domestic workers. Domestic workers were also asked whether their employers made any specific requirements (yes/no answer), without detailing those skills.

Table 1 reports the frequency distribution of the variables in the model.

The data analysis

We applied Multiple Correspondence Analysis (MCA) and Cluster Analysis (CA) to perceive the association between abuses and to classify domestic workers according to the type of abuse, respectively. The MCA was designed in the 1960s and 1970s and 
is a powerful tool to discover and analyse the hidden structure and relationship of a set of qualitative variables (Asselin and Anh, 2008; Di Franco, 2015; Huong et al., 2015). This analysis reduces a large number of qualitative variables to a restricted number of new composite quantitative variables, called dimensions. We used hierarchical Cluster Analysis, with agglomerative procedures (Ward and complete linkage methods with squared Eucledian distance) to validate the number of profiles. A non-hierarchical method, K-means, was used to classify the cases.

Next, we used a multinomial regression model (MLR) to test the association of a set of domestic workers, current job and workplace characteristics with each type of abuse. The MLR at the same time estimates the predictors of J non-ordered outcomes (Powers and Xie, 2000), that is, the factors associated with different types of abuse in domestic work $(J=$ number of types of abuse). The MLR represents an extension of logistic regression that can handle more than two categories of an unordered response variable. It compares each category to an arbitrary reference category providing a set of logistic regression models.

\section{Empirical evidence}

\section{Typologies of abuse in domestic work}

The application of multiple correspondence analysis (MCA) to our categorical data led to two dimensions. The first shows the associations between the categories of workers who stated they were not victims of abuse, as opposed to those who said they were. The second dimension indicates different types of abuse. The spatial distribution of categories shows the first dimension (occurrence of abuse and harassment) in the horizontal axis and illustrates no abuse versus the presence of abuse; the different types of abuse associated with the second dimension are defined in the vertical axis which is labelled types of abuse. The first quadrant depicts the association between several forms of psychological and physical violence. The types of abuse in the fourth quadrant are mostly related to wages and contracts. The second and third quadrants group the 'No' categories, meaning no abuse. In light of this distribution, it seems logical to consider the three profiles illustrated in Figure 1, which displays the projection of these dimensions.

The second step consisted of a cluster analysis (CA) to obtain a typology of abuses from the topology obtained by MCA application. We used hierarchical agglomerative procedures which confirmed the existence of three profiles of abuse suffered by the sampled domestic workers. Technically speaking, we found convergent solutions by analysing dendrograms and agglomeration coefficients (Hair et al., 2010).

Next, we applied a K-means method to classify domestic workers. Cluster analysis confirmed the segmentation of the domestic workers in the sample into three clusters, which we labelled: 'multiple abuses', 'no abuse' and 'labour abuses'.

Table 2 reports the specific types of abuse aggregated in each typology (for details, see Table 2A in Appendix).

The descriptive analysis has already shown that labour abuses were the most common type of abuse in our sample. The estimated clusters suggest the presence of a nonnegligible proportion of domestic workers reporting no abuse (51.8 per cent), while the segment of multiple and more severe abuse affects a small proportion of the sampled workers. 
Table 2 Types of abuse suffered by domestic workers

\begin{tabular}{llll}
\hline \hline & \multicolumn{3}{c}{ Clusters } \\
\cline { 2 - 4 } & $\begin{array}{l}\text { Multiple abuses } \\
(\mathrm{n}=96 ; 14,0 \%) \\
\% \text { of Yes }\end{array}$ & $\begin{array}{l}\text { No abuse } \\
(\mathrm{n}=354 ; 51,8 \%) \\
\% \text { of Yes }\end{array}$ & $\begin{array}{l}\text { Labour abuses } \\
(\mathrm{n}=234 ; 34,2 \%) \\
\% \text { of Yes }\end{array}$ \\
\hline Wage arrears & 49.0 & 14.2 & 56.8 \\
Unpaid allowances & 44.8 & 6.3 & 90.1 \\
Unpaid overtime & 61.5 & 26.4 & 72.4 \\
Unpaid social contributions & & 6.6 & 75.3 \\
Forced to perform tasks & 86.5 & 14.0 & \\
$\quad$ w/o agreement & & & \\
Deprived of rest time & 67.7 & 2.3 & \\
Deprived of food & 28.3 & 1.2 & \\
Deprived of holidays & 41.7 & 2.0 & \\
Sexual harassment & 22.9 & 1.7 & \\
Physical violence & 9.5 & 0.0 & \\
Psychological violence & 45.7 & 1.7 & \\
Discrimination & 52.1 & 5.4 & \\
Forced to perform tasks & 59.4 & 5.1 & \\
$\quad$ against will & & 1.7 & \\
Spatial segregation & 14.7 & & \\
\hline \hline
\end{tabular}

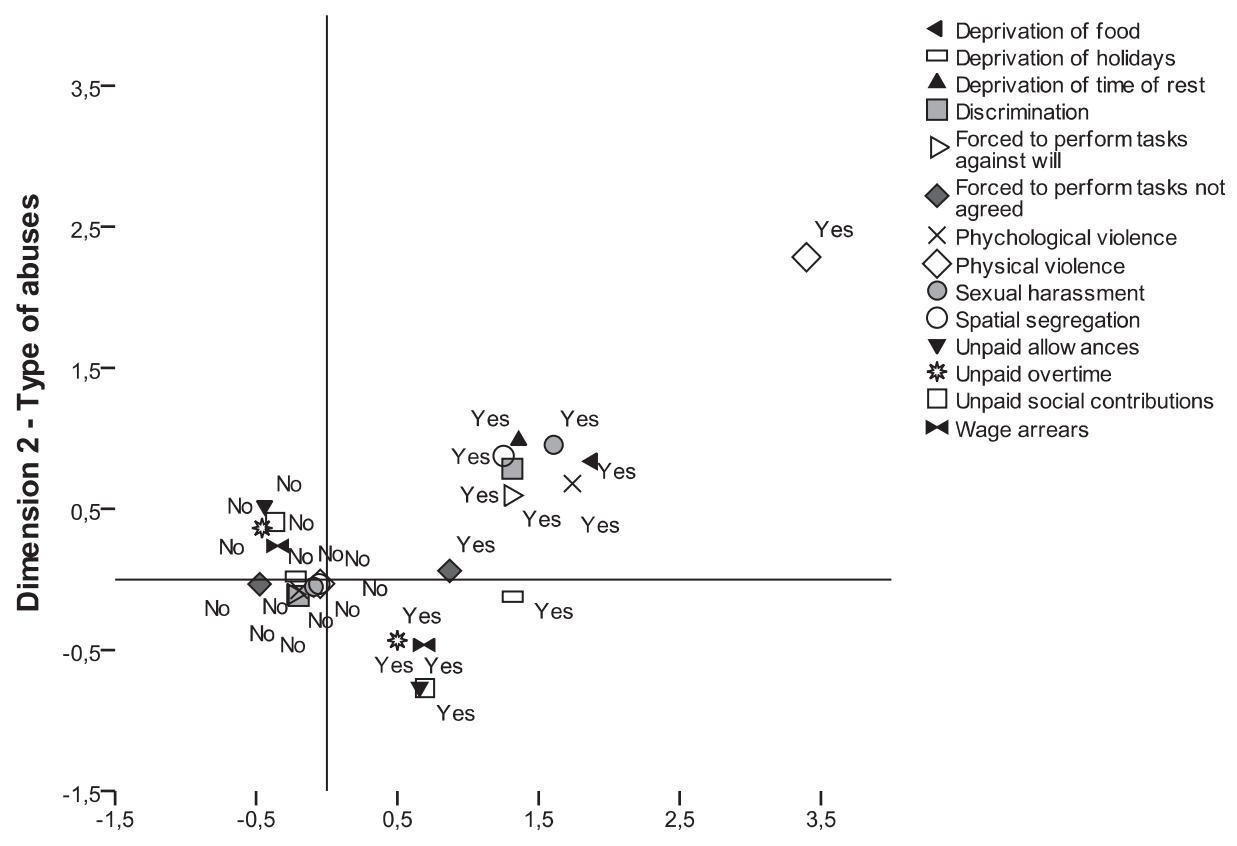

Dimension 1 - Occurence of abuses

Figure 1. Spatial distribution of the risk of abuse 


\section{Predicting abuse in domestic work}

The results from the MLR illustrate that the characteristics vary in line with the types of abuse. We use the no abuse cluster as the reference category and subsequently examine the characteristics that predict multiple abuses and labour abuses. The negative estimates should be interpreted as factors that protect against abuse, while positive estimates suggest an increase in the likelihood of having been a victim.

Our first analysis concentrates on the factors that raise the probability of having been a victim of multiple abuses. The estimates reported in Table 3 indicate that Brazilian and Eastern European workers, carers of the elderly and those working in houses were more vulnerable to all types of abuse. Furthermore, the signs and significance of estimates associated with required skills indicate that general skills or the demand for a specific skill did not protect domestic workers from multiple abuses. On the other hand, domestic workers performing child care tasks and engaged in a maternalist relationship with their employers were less likely to have suffered from multiple abuses.

We note that the sample of workers were protected from labour abuses if they had a formal employment relationship, needed specific skills and worked for a single employer. In addition, trust-related issues, represented by having a key to the house of the current workplace, lowered the probability of this type of abuse. We underline that few characteristics increased the reports of both labour and multiple abuses, notably nationality (Brazilian), and the demand for general skills. On the other hand, a maternalist relationship also reduced the probability of labour and multiple abuses.

In sum, the estimates from the MLR displayed in Table 3 reveal the relative probability of having been a victim based on workers' characteristics, the job and workplace. However, the marginal effects must be calculated from the MLR in order to observe the effect of selected characteristics on each cluster.

The marginal effects reported in Table 4 corroborate previous evidence on factors that increase (decrease) the probability of having been a victim. We now focus on the characteristics associated with reports of no abuse. The domestic workers engaged in formal and maternalist relationships are more likely to be protected from abuse. Furthermore, domestic workers that are entrusted with the key to the house and whose employers demanded specific skills did not report abuse.

However, we note that marginal effects revealed that caring for children did not prevent the risk of wage and contractual-related abuses.

\section{Discussion and conclusion}

Our results provide the literature with further evidence of the variety of abuses experienced by domestic workers in their workplace (Bakan and Stasiulis, 1997; Pereira and Vasconcelos, 2008). Our typology of abuse discriminated between multiple and labour abuses, but also included a cluster of workers that had not been victims. We insist that a non-negligible proportion of workers (51.8 per cent) reported no abuse in the workplace. Furthermore, the smallest group in the sample is the cluster that includes violation of contractual agreements, notably doing additional tasks or doing tasks against the worker's will; lack of food; sexual harassment; psychological violence; and discrimination. In other words, a small group of domestic workers in Portugal were victims of, or at least reported that they were victims of, severe abuses. Overall, employers tend to delay payment or 
Table 3 The predictors of abuse in domestic work

\begin{tabular}{|c|c|c|}
\hline & $\begin{array}{l}\text { Multiple abuses } \\
\text { vs } \\
\text { No abuse }\end{array}$ & $\begin{array}{l}\text { Labour abuses } \\
\text { vs } \\
\text { No abuse }\end{array}$ \\
\hline \multicolumn{3}{|l|}{ Nationality: Native $(\dagger)$} \\
\hline African & $\begin{array}{l}0.0218 \\
(0.4951)\end{array}$ & $\begin{array}{r}-0.2596 \\
(0.3597)\end{array}$ \\
\hline Brazilian & $\begin{array}{l}1.7632^{* * *} \\
(0.4170)\end{array}$ & $\begin{array}{l}0.8540^{* * *} \\
(0.3101)\end{array}$ \\
\hline Eastern European & $\begin{array}{l}1.3554^{* * *} \\
(0.4827)\end{array}$ & $\begin{array}{l}0.0574 \\
(0.4061)\end{array}$ \\
\hline Formality: Social security (Yes = 1) & $\begin{array}{r}-0.2466 \\
(0.3241)\end{array}$ & $\begin{array}{r}-0.4248^{*} \\
(0.2185)\end{array}$ \\
\hline Knowledge of legal rights (Yes $=1$ ) & $\begin{array}{c}0.1909 \\
(0.3139)\end{array}$ & $\begin{array}{l}0.3477 \\
(0.2149)\end{array}$ \\
\hline \multicolumn{3}{|l|}{ Job characteristics: } \\
\hline Live-in status (Multiple employers $\dagger$ ) & $\begin{array}{l}0.2942 \\
(0.4514)\end{array}$ & $\begin{array}{r}-0.3069 \\
(0.3662)\end{array}$ \\
\hline Single employer (Multiple employers $\dagger$ ) & $\begin{array}{c}0.2803 \\
(0.3325)\end{array}$ & $\begin{array}{c}-0.4807^{* *} \\
(0.2391)\end{array}$ \\
\hline Personal traits & $\begin{array}{c}0.1195 \\
(0.1430)\end{array}$ & $\begin{array}{r}-0.0535 \\
(0.1014)\end{array}$ \\
\hline Specific skills & $\begin{array}{r}-0.1936 \\
(0.1409)\end{array}$ & $\begin{array}{c}-0.2439^{* *} \\
(0.1012)\end{array}$ \\
\hline General skills & $\begin{array}{r}0.2568^{*} \\
(0.1403)\end{array}$ & $\begin{array}{l}0.3063^{* * *} \\
(0.1125)\end{array}$ \\
\hline Additional skill requirement $(\mathrm{Yes}=1$ ) & $\begin{array}{l}0.5911^{*} \\
(0.3393)\end{array}$ & $\begin{array}{l}0.7018^{* * *} \\
(0.2456)\end{array}$ \\
\hline \multicolumn{3}{|l|}{ Tasks performed: Cleaning tasks $(\dagger)$} \\
\hline Child care tasks & $\begin{array}{c}-0.7515^{* *} \\
(0.3665)\end{array}$ & $\begin{array}{c}0.3363 \\
(0.2092)\end{array}$ \\
\hline Elderly care tasks & $\begin{array}{r}0.6169^{*} \\
(0.3159)\end{array}$ & $\begin{array}{c}0.3173 \\
(0.2241)\end{array}$ \\
\hline \multicolumn{3}{|l|}{ Trust issues: } \\
\hline Employer present $(\mathrm{Yes}=1$ ) & $\begin{array}{c}0.3936 \\
(0.3207)\end{array}$ & $\begin{array}{r}-0.0757 \\
(0.2142)\end{array}$ \\
\hline Key to the house $($ Yes $=1)$ & $\begin{aligned}-0.4617 \\
(0.3939)\end{aligned}$ & $\begin{array}{r}-0.4575^{*} \\
(0.2432)\end{array}$ \\
\hline Demand for references $(Y e s=1)$ & $\begin{array}{c}0.4870 \\
(0.3587)\end{array}$ & $\begin{array}{l}0.7724^{* * *} \\
(0.2471)\end{array}$ \\
\hline \multicolumn{3}{|l|}{ Employer characteristics: } \\
\hline Household (Yes = 1) & $\begin{array}{r}0.5542^{*} \\
(0.3196)\end{array}$ & $\begin{array}{r}-0.0727 \\
(0.2139)\end{array}$ \\
\hline Maternalist relationship: Gifts (Yes $=1$ ) & $\begin{array}{r}-0.5610^{*} \\
(0.3096)\end{array}$ & $\begin{array}{c}-0.7842^{* * *} \\
(0.2071)\end{array}$ \\
\hline Constant & $\begin{array}{c}-2.0247^{* * *} \\
(0.5039)\end{array}$ & $\begin{array}{l}0.0247 \\
(0.3439)\end{array}$ \\
\hline $\begin{array}{l}\text { Pseudo R } \\
\text { Observations }\end{array}$ & \multicolumn{2}{|c|}{0.1180} \\
\hline
\end{tabular}

Notes: (†) Reference categories. $\left(^{*}\right)$ Statistically significant at the 0.10 level; $\left({ }^{* *}\right)$ at the 0.05 level; $\left({ }^{* * *}\right)$ at the 0.01 level. 
Table 4 Marginal effects from multinomial logistic regression model (significant estimates)

\begin{tabular}{|c|c|c|c|}
\hline & Multiple abuses & No abuse & Labour abuses \\
\hline Probability & 0.0978 & 0.5529 & 0.3493 \\
\hline \multicolumn{4}{|l|}{ Nationality: Native $(\dagger)$} \\
\hline \multicolumn{4}{|l|}{ African } \\
\hline Brazilian & $\begin{array}{l}0.1776^{* * *} \\
(0.0628)\end{array}$ & $\begin{array}{c}-0.2685^{* * *} \\
(0.0651)\end{array}$ & \\
\hline European & $\begin{array}{l}0.1801^{* *} \\
(0.0814)\end{array}$ & & \\
\hline Formality: Social security $($ Yes $=1)$ & & $\begin{array}{r}0.0983^{*} \\
(0.0513)\end{array}$ & $\begin{array}{r}-0.0921^{*} \\
(0.0501)\end{array}$ \\
\hline \multicolumn{4}{|l|}{ Knowledge of legal rights (Yes $=1$ ) } \\
\hline \multicolumn{4}{|l|}{ Job characteristics: } \\
\hline Single employer (Multiple employer $\uparrow$ ) & & & $\begin{array}{c}-0.1151^{* *} \\
(0.0475)\end{array}$ \\
\hline \multicolumn{4}{|l|}{ Personal traits } \\
\hline Specific skills & & $\begin{array}{l}0.0576^{* *} \\
(0.0232)\end{array}$ & $\begin{array}{l}-0.04881^{* *} \\
(0.0218)\end{array}$ \\
\hline General skills & & $\begin{array}{c}-0.0730^{* * *} \\
(0.0254)\end{array}$ & $\begin{array}{l}0.0608^{* *} \\
(0.0243)\end{array}$ \\
\hline Additional skill requirement $(Y e s=1)$ & & $\begin{array}{l}-0.1679^{* * *} \\
(0.0556)\end{array}$ & $\begin{array}{l}0.1411^{* *} \\
(0.0554)\end{array}$ \\
\hline \multicolumn{4}{|l|}{ Tasks performed: Cleaning tasks $(\dagger)$} \\
\hline Child care tasks & $\begin{array}{c}-0.0715^{* * *} \\
(0.0244)\end{array}$ & & $\begin{array}{l}0.1015^{* *} \\
(0.0466)\end{array}$ \\
\hline Elderly care tasks & & $\begin{array}{r}-0.0957^{*} \\
(0.0514)\end{array}$ & \\
\hline \multicolumn{4}{|l|}{ Trust issues: } \\
\hline \multicolumn{4}{|l|}{ Employer present (Yes = 1) } \\
\hline Key to the house $($ Yes $=1)$ & & $\begin{array}{l}0.1138^{* *} \\
(0.0579)\end{array}$ & \\
\hline Demand for references $(Y e s=1)$ & & $\begin{array}{c}-0.1766^{* * *} \\
(0.0560)\end{array}$ & $\begin{array}{l}0.1634^{* * *} \\
(0.0567)\end{array}$ \\
\hline \multicolumn{4}{|l|}{ Employer characteristics: } \\
\hline Household $($ Yes = 1) & $\begin{array}{r}0.0545^{*} \\
(0.0230)\end{array}$ & & \\
\hline Maternalist relationship: Gifts (Yes $=1$ ) & & $\begin{array}{l}0.1807^{* * *} \\
(0.0464)\end{array}$ & $\begin{array}{c}-0.1589^{* * *} \\
(0.0451)\end{array}$ \\
\hline Observations & & 547 & \\
\hline
\end{tabular}

Notes: (†) Reference categories. $\left(^{*}\right)$ Statistically significant at the 0.10 level; $\left({ }^{* *}\right)$ at the 0.05 level; $\left({ }^{* * *}\right)$ at the 0.01 level.

force domestic workers to do tasks that were not part of the initial agreement (Pereira and Vasconcelos, 2008). The results obtained so far suggest that Portugal varies in the degree and kind of abuse suffered by domestic workers.

However, our analysis strived to open the discussion on the factors that raise/lower the probability of being a victim of each type of abuse. The estimates from the MLR 
allowed us to discriminate between risk factors and protection factors and therefore make a valuable contribution to the literature. Both institutional reports (ILO, 2010) and the literature reported in this paper have hitherto focused almost exclusively on risk factors, i.e. those that raise the probability of being a victim of abuse.

The MLR results confirm findings that highlight migrant domestic workers' vulnerability to more severe abuses (Hypothesis 1) (Huling, 2011; Lin, 1999). In addition, we find that not all migrant workers are mistreated in the same way. In relation to their native counterparts, the estimate shows that African domestic workers do not have a significant probability of suffering any type of abuse, and that Brazilian workers are the most vulnerable. A racial hierarchy was an additional source of discrimination against migrant workers, as reported in other countries where migrants from different countries compete for jobs in domestic work (Jueridin and Moukarbel, 2004). The results clearly pointed to the 'triple' prejudice faced by domestic workers, namely as women, migrants and Brazilian migrants (Hypothesis 2).

Our results corroborate the statements of Brazilian migrants on their vulnerability to severe abuses; the Brazilians in our sample state they were victims of multiple abuses including sexual abuse and harassment. However, we are unable to confirm whether Brazilian migrants are more willing to report severe abuses than either other migrants or Portuguese domestic workers.

We found no evidence showing that knowledge of legal rights lessens abuse. While the worker may benefit from taking their employer to court on the grounds of illegal practices, this does not contribute significantly to reducing the probability of abuse (Hypothesis 3). We suggest two reasons for this finding: this knowledge leads workers to exercise their legal rights; employers are aware of the cost of workers' claims of abuse and harassment.

Unlike previous studies (e.g. Cruz and Klinger, 2011), our evidence does not confirm the significant vulnerability of live-in workers. This may be because the domestic workers changed jobs after suffering abuse when working in a live-in arrangement. Although estimates from the regression model are not statistically significant, the individual data provide accounts of live-in workers having to be on call twenty-four hours a day.

These statements clearly indicate that employers fail to acknowledge the needs of live-in workers (Kontos, 2014). Accordingly, full-day working hours presupposes defamilialisation, which means that the provision of care should be the domestic worker's priority. As a result, we suspect that this expresses a colonial mentality in the management of live-in workers in Portugal (Gomes, 2012). According to Kontos' (2014) arguments, employers expect total availability and consider it an intrinsic and unquestionable characteristic of live-in work. Further scrutiny and additional data on live-in workers are therefore required to validate our Hypothesis 4.

However, these workers tend to care for the elderly and, according to our estimates, in fact they appeared vulnerable to multiple abuses. In other words, the perpetrator might be the receiver of care and the abuse occurs during work-related interaction (Merchant and Lundell, 2001). Nevertheless, domestic workers recognise that mental health issues may trigger this behaviour and therefore excuse it (Gomes, 2012).

Turning now to protection factors - more specifically, predictors of what might prevent abuse. Firstly, the negative sign associated with gifts challenges Romero's (1992) argument of a substitution effect. In other words, workers who receive gifts from their employers are less likely to report any type of abuse. We therefore understand these gifts to be attempts 
to show kindness, benevolence and care for domestic workers (Bakan and Stasiulis, 1997) rather than as a substitute for higher wages (Hypothesis 5). However, we are unable to examine other motivations of employers associated with gifts. Probably, employers expect reciprocity or attempt to reinforce the asymmetric relationship (Kontos, 2014; Tappert and Dobner, 2015); these arguments call for more detailed analysis.

Other predictors deserve attention, namely the role of formality, specific skills, trust issues and the type of employment relationship (see marginal effects in Table 4). As reported, employers in Portugal are legally obliged to register the employment relationship with the social security authorities. We found that formality through this registration reduces the probability of contractual and wage abuses (-0.0921). This corroborates the argument made by Cox and Watt (2002) that employers benefit from informality. It also underlines the role played by the formal relationship in the protection of domestic workers from labour abuses in particular, but also in the prevention of all abuse (0.0983) (Hypothesis 6).

Furthermore, marginal effects help identify protecting factors. For example, like formality, the demand for specific skills prevented abuse in domestic work. It seems that employers are aware of the difficulty of hiring and replacing domestic workers (Anderson, 2007). Employers appeared to protect domestic workers from abuse in order to shield their home; domestic workers in the sample entrusted with the key to the house were protected from abuse (0.1138).

However, carers of children suffered labour abuses (0.1015) but were less likely to report multiple abuses $(-0.0715)$. Employers were often unable to fulfil their obligations despite recognising the specificities of care services, especially emotional labour, that is affective relations in child care. Delays in the payment of wages and other remuneration owed to workers are not unusual in domestic work (Pereira and Vasconcelos, 2008; GAMI, 2012). The figures in Table 2 indicate that employers fail to comply with the payment of allowances, social contributions and overtime in particular.

This behaviour reveals households either find it difficult to pay for labour services and non-wage costs or, alternatively, voluntarily mistreat their domestic workers. This raises questions however on the extent to which employers are aware of the vulnerability of their children or elderly relatives (elderly caregivers have a negative probability of reporting no abuses (-0.0957)) to mistreatment from domestic workers.

We suggest that although policy makers and scholars recognise domestic workers' need for decent work and job quality, they often overlook these predictors. Policy makers should be aware of factors that lower the risk of abuse in domestic work. Our study makes a valuable contribution to this by detailing and quantifying the potential risk and protection factors. The results obtained highlight the significance of employers' willingness to comply with their legal requirement to formalise and comply with the applicable legal requirements for the employment relationship. In return, they can expect domestic workers to protect their home and family members. All social and political actors must take initiatives to encourage employers to develop and maintain a healthy employeremployee relationship, which is beneficial to both parties.

Our sample is small and based on snowball sampling and therefore far from random. However, this sampling method is suitable for this particular labour market as it gives us access to irregular situations. Furthermore, we are unable to clearly discriminate when the domestic worker experienced the abuse, that is, in the current job and/or the previous one(s). Despite the social and political relevance of our empirical evidence, all results 
must be regarded with circumspection. We opened the discussion on risk and protection factors in this study. Further inquiries into abuse should account for the temporal match between the abuse experienced and the job where it happened.

Nevertheless, a distinction should be made between the very severe abuses documented in other countries and the abuse described by domestic workers in Portugal. Our findings confirmed the prevalence of 'labour abuses' and showed in addition that severe abuses seem to be uncommon. So, further research is required to cluster countries according to the degree, kind and frequency of abuse as this would help policy makers to set appropriate regulations.

\section{Acknowledgements}

This research was possible thanks to data collected within Domestic Work and Domestic Workers: Interdisciplinary and Comparative Perspectives project granted by FCT - Foundation of Science and Technology, of Ministry of Education and Science PTDC/JUR/65622/2006. We gratefully acknowledge the comments from participants at XI Jornadas de Economía Laboral in Bellaterra, Barcelona, 1-3 July 2015; the Fourth Conference of the Regulating for Decent Work Network, Geneva, 8-10 July 2015; and CICOT 2015 3rd International Congress on Working Conditions Porto, 10-11 September, 2015.

\section{Notes}

1 See Mayhew (2012) for some figures on variations across industries, occupations and gender.

2 The authors propose four categories of workplace violence: type I, there is no relationship between perpetrator and the victim; type II, where care receiver is the perpetrator; type III where the violence occurs among workers; and type IV where perpetrator has a personal relationship with the victim (Merchant and Lundell, 2001).

3 For detailed examples of these conditions see Human Right Watch: http://www.hrw.org/search/ apachesolr_search/domestic\%20worker. Complaints are also made about how employers benefit from the lack of regulations in the domestic workers labour market (e.g. http://apirnet.ilo.org/news/some-employerstake-advantage-of-weak-legal-protection-walls-at-every-turn-for-domestics).

4 See also Pereira and Vasconcelos (2008) for comparison across industries for Portugal.

5 http://www.comunidaria.org/conhecer.php

6 This should be treated with caution as we have no further information on whether Brazilian are more frequently sexually abused than other migrants or whether they tend to report more than others.

\section{References}

Abrantes, M. (2012) 'A densidade da sombra. Trabalho doméstico, género e imigração', Sociologia, Problemas e Práticas, 70, 91-110.

Anderson, B. (2000) Doing the Dirty Work? The Global Politics of Domestic Labour, London and New York: Zed Books.

Anderson, B. (2001) 'Just another job? Paying for domestic work', Gender and Development, 9, 1, $25-33$. Anderson, B. (2004) 'Migrant domestic workers and slavery', in C. van den Anker (ed.), The Political Economy of New Slavery, Basingstoke, UK: Palgrave Macmillan, 107-17.

Anderson, B. (2007) 'A very private business: exploring the demand for migrant domestic workers', European Journal of Women's Studies, 14, 3, 247-64. 
Arat-Koc, S. (1989) 'In the privacy of our own home: foreign domestic workers as solution to the crisis in the domestic sphere in Canada', Studies in Political Economy, 28, 33-58.

Asselin, L. M. and Anh, V. T. (2008) 'Multidimensional poverty and multiple correspondence analysis', Quantitative Approaches to Multidimensional Poverty Measurement, Basingstoke, UK: Palgrave Macmillan, 80-103.

Bakan, A. B. and Stasiulis, D. K. (1997) Not One of the Family: Foreign Domestic Workers in Canada, University of Toronto Press.

Blackett, A. (2011) 'Introduction: regulating decent work for domestic workers', Canadian Journal of Women and the Law, 23, 1, 1-45.

Boyd, M. and Pikkov, D. (2008) 'Finding a place in stratified structures: migrant women in North America', in Nicole Piper (ed.), New Perspectives on Gender and Migration: Livelihoods, Rights, and Entitlements, United Nations Research Institute for Social Development, 19-58.

Burnham, L. and Theodore, N. (2012) Home Economics: The Invisible and Unregulated World of Domestic Work, New York, NY: National Domestic Workers Alliance.

Caracciolo, B., Henry, G. and Rosenbusch, S. (2011) Domestic Workers: From Modern-day Slavery to Equal Rights, Decent Work, Decent Life, SOLIDAR Briefing 30.

Chappell, D. and Di Martino, V. (2006) Violence at Work, 3rd edn, Geneva: International Labour Office.

Chen, M. A. (2011) 'Recognizing domestic workers, regulating domestic work: conceptual, measurement, and regulatory challenges', Canadian Journal of Women and the Law, 23, 1, 167-84.

Cox, R. and Watt, P. (2002) 'Globalization, polarization and the informal sector: the case of paid domestic workers in London', Area, 34, 1, 39-47.

Cruz, A. and Klinger, S. (2011) Gender-based Violence in the World of Work: Overview and Selected Annotated Bibliography, Geneva: International Labour Office.

De Ruijter, E., Van der Lippe, T. and Raub, W. (2003) 'Trust problems in household outsourcing', Rationality and Society, 15, 4, 473-507.

Di Franco, G. (2015) 'Multiple correspondence analysis: one only or several techniques?', Quality and Quantity, 50, 3, 1299-315.

Du Toit, D. (ed.) (2013) Exploited, Undervalued - and Essential: Domestic Workers and the Realisation of Their Rights, Pretoria, South Africa: Pretoria University Law Press (PULP).

Dyer, S., McDowell, L. and Batnitzky, A. (2008) 'Emotional labour/body work: the caring labours of migrants in the UK's National Health Service', Geoforum, 39, 6, 2030-8.

Ehrenreich, B. and Hochschild, A. R. (2002) Global Woman: Nannies, Maids and Sex Workers in the New Economy, New York: Metropolitan Books.

GAMI (2012) Direitos e Deveres no Trabalho Doméstico, Lisbon: GAMI, http://www.solimigrante.org/ wp-content/uploads/2012/04/Brochura-Direitos-e-Deveres_final2.pdf.

Glenn, E. N. (1992) 'From servitude to service work: historical continuities in the racial division of paid reproductive labor', Signs, 18, 1, 1-43.

Gomes, C. (2012) 'O invisível mundo dos abusos contra as trabalhadoras domésticas', Público, http://www.publico.pt/portugal/jornal/o-invisivel-mundo-dos-abusos-contra-as-trabalhadorasdomesticas-24626828.

Guibentif, P. (2011) Rights Perceived and Practiced, results of the survey carried out in Portugal as part of the project: 'Domestic Work And Domestic Workers Interdisciplinary and Comparative Perspectives', Working Paper DINÂMIA'CET-IUL 143, Lisbon: Instituto Universitário de Lisboa.

Hair, J., Anderson, R., Tatham, R. and Black, W. (2010) Multivariate Data Analysis: A Global Perspective, 7th edn, Upper Saddle River: Pearson International Edition.

Himmelweit, S. (2007) 'The prospects for caring: economic theory and policy analysis', Cambridge Journal of Economics, 31, 4, 581-99.

Huong, P. N. A., Hamid, H. and Aziz, N. (2015) 'Multiple correspondence analysis for handling large binary variables in smoothed location model', Innovation and Analytics Conference and Exhibition (IACE 2015): Proceedings of the 2nd Innovation and Analytics Conference \& Exhibition, 1691, AIP Publishing. 
Huling, A. (2011) 'Domestic workers in Malaysia: hidden victims of abuses and forced labor', International Law and Politics, 44, 629-80.

International Labour Office (ILO) (2010) Decent Work for Domestic Workers Fourth Item on the Agenda, Geneva: International Labour Office.

International Labour Office (ILO) (2013) Domestic Workers across the World: Global and Regional Statistics and the Extent of Legal Protection, Geneva: International Labour Office.

Jokela, M. (2015) 'Macro-level determinants of paid domestic labour prevalence: a cross-national analysis of seventy-four Countries', Social Policy and Society, 14, 3, 385-405.

Jureidini, R. and Moukarbel, N. (2004) 'Female Sri Lankan domestic workers in Lebanon: a case of "contract slavery"?', Journal of Ethnic and Migration Studies, 30, 4, 581-607.

Kontos, M. (2013) 'Negotiating the social citizenship rights of migrant domestic workers: the right to family reunification and a family life in policies and debates', Journal of Ethnic and Migration Studies, 39, 3, 409-24.

Kontos, M. (2014) 'Recognition Dynamics in a Misrecognised Job: Domestic and Care Work of Migrant Women in Europe', Frankfurt, IFS Working Paper 4.

Lan, P. C. (2003) 'Political and social geography of marginal insiders: migrant domestic workers in Taiwan', Asian and Pacific Migration Journal, 12, 1-2, 99-125.

Leitner, S. (2003) 'Varieties of familialism: the caring function of the family in comparative perspective', European Societies, 5, 4, 353-75.

León, M. (2010) 'Migration and care work in Spain: the domestic sector revisited', Social Policy and Society, 9, 3, 409-18.

Lin, C. J. (1999) Filipina Domestic Workers in Taiwan: Structural Constraints and Personal Resistance, Taipei: Taiwan Grassroots Women Workers' Centre.

Liu, J. (2014) 'Accession protocols: legal status in the WTO legal system', Journal of World Trade, 48, 4, $751-71$.

Mayhew, C. (2012) 'Occupational violence in industrialized countries: types, incidence patterns and "at risk" groups of workers', M. Gill, B. S. Fisher and V. Bowie (eds.), Violence at Work: Causes, Patterns and Prevention, London and New York: Routledge Taylor \& Francis Group.

Meagher, G. (1997) 'Recreating "domestic service": institutional cultures and the evolution of paid household work', Feminist Economics, 3, 2, 1-27.

Merchant, J.A. and Lundell, J. A. (2001) 'Workplace violence intervention research workshop: background, rationale and summary', American Journal of Preventive Medicine, 20, 2, 135-40.

Moras, A. (2008) 'The private home as a public workplace: employing paid domestic labour', Journal Workplace Rights, 13, 4, 377-400.

Moya, J. C. (2007) 'Domestic service in global perspective: gender, migration and ethnic niches', Journal of Ethnic and Migration Studies, 33, 4, 559-79.

Parreñas, R. (2000) 'Migrant Filipina domestic workers and the international division of reproductive labor', Gender and Society, 14, 4, 560-80.

Pereira, S. (2013) 'Replacement migration and changing preferences: immigrant workers in cleaning and domestic services in Portugal', Journal of Ethnic and Migration Studies, 39, 7, 1141-58.

Pereira, S. and Vasconcelos, J. (2008) Human Trafficking and Forced Labour: Cases Studies and Responses from Portugal, Geneva: International Labour Office.

Powers, D. A. and Xie, Y. (2000) Statistical Methods for Categorical Data Analysis, San Diego: Academic Press.

Raghuram, P. (2001) 'Caste and gender in the organisation of paid domestic work in India', Work, Employment and Society, 15, 3, 607-17.

Reyneri, E. (2003) 'Immigration and the underground economy in new receiving South European countries: manifold negative effects, manifold deep-rooted causes', International Review of Sociology (Revue Internationale de Sociologie), 13, 1, 117-43.

Rodriguez, R. (2008) 'Domestic debates: constructions of gendered migration from the Philippines', The Scholar and Feminist Online 6, 3: http://sfonline.barnard.edu/immigration/rrodriguez_01.htm. 
Rollins, J. (1985) Between Women: Domestic and their Employers, Philadelphia, Temple University Press. Romero, M. (1992) Maid in the USA, New York: Routledge.

Suleman, F. (2015) 'The employment relationship in an (almost) structureless labour market: the case of domestic work', Cambridge Journal of Economics, 39, 3, 733-50.

Tappert, S. and Dobner, M. (2015) 'Being a member of the family? Meanings and implications in paid migrant domestic and care work in Madrid', M. Kontos and G. T. Bonifácio (eds.), Migrant Domestic Workers and Family Life: International Perspectives, Basingstoke, UK: Palgrave Macmillan, 276-99.

Um, S-G. (2015) 'Struggling to make time for family: work and family life of Korean-Chinese institutional care workers in the South Korea', in M. Kontos and G. T. Bonifacio (eds.), Migrant Domestic Workers and Family Life: International Perspectives, Basingstoke, UK: Palgrave Macmillan, 257-75.

Wall, K. and Nunes, C. (2010) 'Immigration, welfare and care in Portugal: mapping the new plurality of female migration trajectories', Social Policy and Society, 9, 3, 431-41.

\section{Appendix}

Table 1A The self-perception of relevant skills: principal component analysis

\begin{tabular}{ll}
\hline \hline PCA factors: Explained variance (Cronbach Alpha) & Skills and abilities \\
\hline Factor 1: Personal traits & Personal service (dealing with people) \\
$26.6 \%(0.695)$ & $\begin{array}{l}\text { Problem solving } \\
\text { Discretion } \\
\end{array}$ \\
& Humility \\
& Job satisfaction \\
Factor 2: Specific skills & Care experience \\
$9.6 \%(0.686)$ & Active listening \\
& Counselling \\
Factor 3: Flexibility & Ability to adapt \\
$9.3 \%(0.381)$ & Work autonomy \\
& Rapidity \\
Factor 4: General skills & General experience \\
$7.95 \%(0.526)$ & Availability \\
& Training \\
\hline \hline
\end{tabular}


Table 2A Clusters of abuses

\begin{tabular}{|c|c|c|c|c|c|c|c|}
\hline & & \multicolumn{6}{|c|}{ Cluster } \\
\hline & & \multicolumn{2}{|c|}{$\begin{array}{l}\text { Multiple } \\
\text { abuses }\end{array}$} & \multicolumn{2}{|c|}{$\begin{array}{l}\text { No } \\
\text { abuse }\end{array}$} & \multicolumn{2}{|c|}{$\begin{array}{l}\text { Labour } \\
\text { abuses }\end{array}$} \\
\hline & & $\mathrm{n}$ & $\%$ & $\mathrm{n}$ & $\%$ & $\mathrm{n}$ & $\%$ \\
\hline \multirow[t]{2}{*}{ Wage arrears } & Yes & 47 & 49.0 & 50 & 14.2 & 133 & 56.8 \\
\hline & No & 49 & 51.0 & 303 & 85.8 & 101 & 43.2 \\
\hline \multirow[t]{2}{*}{ Unpaid allowances } & Yes & 43 & 44.8 & 22 & 6.3 & 209 & 90.1 \\
\hline & No & 53 & 55.2 & 330 & 93.8 & 23 & 9.9 \\
\hline \multirow[t]{2}{*}{ Unpaid overtime } & Yes & 56 & 61.5 & 92 & 26.4 & 168 & 72.4 \\
\hline & No & 35 & 38.5 & 257 & 73.6 & 64 & 27.6 \\
\hline \multirow[t]{2}{*}{ Unpaid social contributions } & Yes & 36 & 38.3 & 23 & 6.6 & 174 & 75.3 \\
\hline & No & 58 & 61.7 & 326 & 93.4 & 57 & 24.7 \\
\hline \multirow[t]{2}{*}{ Forced to perform tasks not agreed } & Yes & 83 & 86.5 & 49 & 14.0 & 110 & 47.0 \\
\hline & No & 13 & 13.5 & 301 & 86.0 & 124 & 53.0 \\
\hline \multirow[t]{2}{*}{ Deprived of rest time } & Yes & 65 & 67.7 & 8 & 2.3 & 17 & 7.3 \\
\hline & No & 31 & 32.3 & 342 & 97.7 & 217 & 92.7 \\
\hline \multirow[t]{2}{*}{ Deprived of food } & Yes & 26 & 28.3 & 4 & 1.2 & 10 & 4.3 \\
\hline & No & 66 & 71.7 & 343 & 98.8 & 224 & 95.7 \\
\hline \multirow[t]{2}{*}{ Deprived of holidays } & Yes & 40 & 41.7 & 7 & 2.0 & 52 & 22.2 \\
\hline & No & 56 & 58.3 & 344 & 98.0 & 182 & 77.8 \\
\hline \multirow[t]{2}{*}{ Sexual harassment } & Yes & 22 & 22.9 & 6 & 1.7 & 9 & 3.8 \\
\hline & No & 74 & 77.1 & 347 & 98.3 & 225 & 96.2 \\
\hline \multirow[t]{2}{*}{ Physical violence } & Yes & 9 & 9.5 & 0 & .0 & 0 & .0 \\
\hline & No & 86 & 90.5 & 353 & 100.0 & 233 & 100.0 \\
\hline \multirow[t]{2}{*}{ Psychological violence } & Yes & 43 & 45.7 & 6 & 1.7 & 19 & 8.1 \\
\hline & No & 51 & 54.3 & 347 & 98.3 & 215 & 91.9 \\
\hline \multirow[t]{2}{*}{ Discrimination } & Yes & 50 & 52.1 & 19 & 5.4 & 21 & 9.0 \\
\hline & No & 46 & 47.9 & 334 & 94.6 & 213 & 91.0 \\
\hline \multirow[t]{2}{*}{ Forced to perform tasks against will } & Yes & 57 & 59.4 & 18 & 5.1 & 30 & 12.8 \\
\hline & No & 39 & 40.6 & 334 & 94.9 & 204 & 87.2 \\
\hline \multirow[t]{2}{*}{ Spatial segregation } & Yes & 14 & 14.7 & 6 & 1.7 & 7 & 3.0 \\
\hline & No & 81 & 85.3 & 346 & 98.3 & 225 & 97.0 \\
\hline
\end{tabular}

